\title{
Analysis of nomofobic behaviors of adolescents regarding various factors
}

\author{
Deniz Mertkan Gezgin ${ }^{1}$ \\ Özlem Çakır ${ }^{2}$
}

\begin{abstract}
Although the developments in technology have made our lives and daily activities easier, it is believed that problematic and excessive use of technology could have some negative effects on people. One of these negative effects is the prevalence of nomophobia, which is considered as a new phobia in recent years. Nomophobia is defined as the fear and anxiety when an individual cannot access his or her mobile/smart phone or cannot have the chance to communicate online and offline via mobile devices. Nomophobic tendencies can change individuals' daily habits. Negative emotions due to nomophobic tendencies like fear and anxiety especially in young people is thought to affect their school lives and academic achievements. The purpose of this research is to analyze the prevalence of nomophobia among high school students regarding various factors. The Nomophobia Scale (NMP-Q), which was used in this study, was developed by Yildirim and Correia (2015), and adapted into Turkish by Yildirim, Sumuer, Adnan and Yildirim (2015). The study group consists of 475 high school students attending six different schools situated in diverse socio-economic areas in Izmir and Edirne in 2015-2016 education year. The study was conducted in survey model and descriptive statistics. T-test for independent samples and one-way analysis of variance (ANOVA) techniques were used at the analysis stage. According to the findings, mean scores obtained from the scale demonstrated that the levels of nomophobic behaviors of high school students were above the average. Besides, female students have higher nomophobia levels compared to male students in terms of gender variable and a significant difference was found in terms of the duration of mobile internet usage. A significant difference could not be found in terms of the variables such as grade, parents' education levels, and the duration of smartphone usage. Furthermore, the study has revealed that high school students use their smartphones and mobile internet largely for social networks, music, communication, photographs, education, research, games and videos.
\end{abstract}

Keywords: Nomophobia; Smartphones; Mobile Technologies; Adolescents; Mobile Internet Usage.

\section{Introduction}

Today, technology has become an irreplaceable part of our lives. Especially mobile technologies and the use of smartphones are rapidly becoming widespread. Our lives have become easier and many daily activities can be performed more easily thanks to smartphones. In addition to communication, individuals can have many applications such as social networks, address book, data

\footnotetext{
1 Assistant Prof. Dr., Trakya University, Faculty of Education, Department of Computer Education and Instructional Technology, mertkan@,trakya.edu.tr

2 Assoc. Prof. Dr., Ankara University, Faculty of Educational Science, Department of Computer Education and Instructional Technology, ocakir@ankara.edu.tr
} 
storage unit, video camera, time applications (time, calendar, chronometer...etc.), video player, navigation and recently online banking and applications for buying or booking all kinds of tickets in a single smartphone. Moreover, the prevalence of mobile internet, availability of Wi-Fi, increasing capacity of mobile phones (speed, capacity, operating system...etc.) and a decrease in the prices could be the reasons for the widespread use of smartphones. According to Internet and Social Media User statistics prepared by We Are Social (2015), the number of internet users in 30 countries including Turkey has increased by 525 million people compared to last year and this result indicates that 3 billion people across the world have access the Internet. The same report also reported that there are approximately 69.6 million mobile users in Turkey. According to the results of the study conducted by Turkish Statistical Institute (TSI) (2015), it was reported that the $96.8 \%$ of the households in Turkey have mobile phones. The same report gave the rate of internet users as $55.9 \%$. The rate of the households that have internet access was given as $69.5 \%$ across Turkey in April, 2015. It was reported that while $74.4 \%$ of the individuals use mobile or smartphones to access the Internet outside home and work, $28.9 \%$ of them use mobile computers such as laptop, notebook, tablet etc. to access the Internet in the first three months of 2015 . When daily usage rates were examined, internet users in Turkey spend approximately 4 hours 37 minutes on the Internet, 2 hours 51 minutes on mobile internet and 2 hours 56 minutes on social media (We Are Social, 2015). As it can be seen, the prevalence of smartphones and wireless internet increases the use of both internet and smartphones.

Mobil devices are more widely used among young population (Kennedy, et al. 2008). This is because young people adopt technology faster than the rest of the population, they follow the latest advancements and developments earlier than other people do (Karaaslan \& Budak, 2012). In addition to this, it was stated that $15 \%$ of American young population between the ages of 18-29 are mainly dependent on smartphones for internet access (Smith, 2015). In a study conducted in Belarus, all $(100 \%)$ students used mobile phones to make and receive calls. More than half $(58.8 \%)$ of 94 respondents used mobile phones to send text messages. Almost 33\% used the phones to take photos. Only $30(18.8 \%)$ of the respondents used cellular phones for games and $41(25.6 \%)$ used the phones to access to the Internet (Szpakow, Stryzhak \& Prokopowicz, 2011). Several studies show that young people and many college students mostly use their mobile devices for social networking, listening to music, watching videos and playing games and they consider smartphones mainly as a leisure device (Chen \& Denoyelles, 2013; Lepp, Li \& Barkley, 2015; Lepp, Barkley, Sanders, Rebold \& Gates, 2013, Lepp, Barkley \& Karpinski, 2015). In addition, smartphone use is a dominant and defining characteristic of this generation of college students and often occurs during class time, while completing homework, and studying (Smith, Raine \& Zickuhr, 2011; Tindell \& Bohlander, 2012). Although young individuals use smartphones and tablet computers mostly for accessing the Internet, social networking, listening to music and watching videos, mobile technologies have started to be used formally and informally in educational activities. Mobile devices are particularly preferred for data storage, course materials, e-books, timetables and reaching information (Sarrab, 2015). Chen and Denoyelles (2013) have stated that mobile technologies increasingly play an important role in academic lives of university students. Yang, Hwang, Hung and Tseng (2013) reported that recent improvements and advancements in mobile technologies provide opportunities for new educational experiences and the activities of acquiring information. This new educational experience and approach is called mobile learning because learning content is integrated into these mobile devices (Garry Wei-Han, Keng-Boon, Lai-Ying, \& Binshan, 2014; Toteja \& Kumar, 2012). According to Berson and Berson (2003), internet is a resource that enables young individuals to reach information and do research; besides, it supports the development of some skills like problem solving, creativity and critical thinking. Likewise, it was reflected that the Internet in an academic sense is a very important tool for teenagers and adults in terms of instant reach of information and communication with others (Ko et al., 2012). 
It is a fact that the use of smartphones and the Internet makes our daily lives easier in every aspect. However, the misuse and excessive use of the Internet bring about various physical, behavioral and psychological problems along with it. To give an example, individuals could be addicted to the Internet and consequently, they could have depression, low self-esteem, oversensitivity, guilt and despair. King et al. (2014) conducted a study in Brazil and examined the symptoms and emotional imbalances of the patients with panic attack due to the use of mobile phone. In an experimental study in which 120 people participated, it was found that both the experiment group including patients with panic disorder and the control group including healthy people exhibit "addiction" to mobile phones. However, it was reported that people with panic disorder are likely to show more intense emotional changes and physical and psychological symptoms in case of not using or reaching mobile phones. King et al. (2014) attributed to the studies claiming that mobile phone addiction indicate the existence of a primary disorder such as social phobia and dependent personality disorder. Samaha and Havi conducted a study on 300 university students and revealed a positive relationship between stress levels and smartphone addiction. Moreover, some studies in the literature suggested that there is a negative relationship between students' academic performance and mobile phone use (Judd, 2014, Karpinski et al., 2013; Rosen et al., 2013, Samaha \& Hawi, 2016; Wentworth \& Middleton, 2014; Kibona \& Mgaya, 2015). The constant checking and/or use of smartphones has been linked to sleep disturbances, stress, anxiety, deterioration in health, a decrease in academic and physical performance (Thomée, Härenstam, \& Hagberg, 2011). Spitzer (2015), who discussed the place of smartphone within the concept of M-learning, claimed they are mostly underestimated and drew the attention to the risks and side effects of smartphones in educational environments through the results obtained from 22 studies conducted in various countries. These risks and side effects include addiction, attention disorder, and empathy deficit disorder, a decrease in academic achievement because of interrupted learning, high blood pressure, obesity, anxiety, depression, personality disorder, aggression, dissatisfaction and loneliness. In the literature, there are many psychological syndromes arising from problematic and excessive use of technology. One of the most important syndromes is nomophobia, which has recently begun to take place in the literature and considered as the phobia of the 21 st century.

\subsection{Nomophobia}

Nomophobia (NO Mobile PHOBIA), which is considered as the modern phobia of the 21st century, is described as the irrational fear when individuals cannot reach their cell phones or smartphones, or they cannot communicate through these mobile devices (King et al., 2013; Yildirim \& Correia, 2015). It is reported that psychological imbalances, which mobile device addicts suffer from, show similar symptoms with those who have psychosocial disorders such as anxiety disorder or mood swings. Individuals who have nomophobic behavior start to feel anxious when they forget their phones, run out of battery or have no network coverage. This anxiety affects individual negatively so they find it difficult to concentrate on their daily activities (Dixit et al., 2010). When the symptoms of nomophobia are examined, if the individual is worried about losing his/her mobile phone even if it is in a safe place, overanxious of losing the signal, never turns off his/her mobile phone or looks at it very often to check whether they have network coverage or low battery, this means that this addiction affects his/her daily life in a negative way (Yenilmez, 2013). Nomophobia, which is also described as the fear of being deprived of mobile phones, is thought to increase in parallel with the prevalence of smartphones.

\subsection{The Prevalence of nomophobia among individuals}

There are limited studies in both statistics and academic field about the prevalence of nomophobia in the society. In a study conducted by Pew Research Center, the $26 \%$ of mobile phone users have stated that they cannot live without their mobile phones (Chen \& Katz, 2009). In a study conducted 
by Post Office over a group of 2.163 people, it was reported that $53 \%$ of cell phone users exhibited nomophobic behaviors and in addition to that, men are more prone to nomophobic behaviors compared to women (Mail Online, 2008). In another study carried out with a group of 1000 working people in England in February 2012 by using OnePoll, it was seen that the number of cell phone users who exhibit nomophobic behaviors has increased in the last four years. Accordingly, $66 \%$ of cell phone users said that the idea of losing their mobile phones causes anxiety and they feel afraid in this sense (SecurEnvoy, 2012). Besides, it was stated that women (70\%) are more anxious than men (61\%) and it was also mentioned that this rate is $77 \%$ among young people between the ages of 18-24 and 68\% between 25-34. It was reported in the literature that the rate of mobile phone usage is higher especially in young population.

In a study carried out with young people in Mumbai, India in 2004, it was found that the participants stated that they could not survive a single day without a cell phone (Macro-Market Analysis \& Consumer Research Organization, 2008). In another study conducted with a group of 200 medical students between the ages of 17-28 in Indore, India, it was found that $18.5 \%$ of the students exhibited nomophobic behaviors. The $73 \%$ of the students stated that they keep their mobile phones near them while sleeping and $20 \%$ of them stated that they lose concentration and feel under pressure when they do not have their mobile phones or run out of battery (Dixit et al., 2010). Another study conducted in India examined the use of mobile phone and the prevalence of nomophobia among third year medical students (Sharma, Sharma, Sharma \& Wavare, 2015). In this study in which 130 students between the ages of $22-24$ participated, it was found that $73 \%$ of the students were nomophobic and $83 \%$ of the students had frequent and recurrent anxiety attacks or panic attacks when they could not find their mobile phones. In a study conducted over university students in France, it was discovered that nearly one third of the students suffered from nomophobia (Tavolacci, Meyrignac, Richard, Dechelotte \& Ladner, 2015). In another study carried out with the participation of 163 university students in the USA in 2014, almost half of the participants' mobile phones were taken and the other half were asked to turn their phones off and put them away. During the period without phones, anxiety scale was administered and results revealed that the participants' anxiety levels increased in this period (Cheever, Rosen, Carrier \& Chavez, 2014). In the studies performed in Turkey, it was found that the nomophobia level of 433 university students in a state university was above average (Gezgin \& Adnan, 2016). The study performed by Yildirim et al. with the participation of 537 university students indicated that $42.6 \%$ $(n=206)$ of the students had nomophobic behaviors. In the study, especially the scores of the factors of "not being able to communicate" and "not being able to reach information" were above average and these two factors had the ultimate priority among youngsters.

\subsection{Nomophobia and its impact on individuals' life}

Nomophobic behaviors can affect our daily habits, family, work and school life. In a study carried out in Korea, $77.4 \%$ of smartphone users check their phones frequently without a reason and more than half of them $(53.9 \%)$ hit their phones before sleeping and the first thing in the morning (Korean Internet and Security Agency, 2012). In the latest research performed by Rosen et al. (2016) with the participation of over 700 university students about the impact of technology on sleep pattern, it was pointed out that at least half of the participants sleep with their mobile phones on. In addition, the majority of them wake up at least once during the night and checks the messages and notifications. The results of the study demonstrated that "the anxiety of losing contact with others" and "the feeling of dependence on technology" could affect their sleep negatively so the students could be unproductive the next day and have difficulty in learning at university. The impact of negative experiences on academic success and school life due to technology dependence and nomophobia was emphasized in Spitzer's (2015) study. 


\subsection{Adolescents and technology}

Keeping in contact through mobile phones in social life starts in childhood period in most parts of the world (Karaaslan \& Budak, 2012). Smartphones as a new mobile technology that change the patterns of social life eliminate social boundaries and existing forms. Technology age has brought mobile phones into a state of significance and it has a great effect on the social and emotional development of adolescents. During the transition stages from childhood to adolescence, the use of media increases (Rideout et al., 2010). Most teenagers spend their time on electronic media platforms (Willemse et al., 2012). These technological devices, which are extremely popular among teenagers, also cause them to change their lifestyles and differ their way of establishing social relations; as a result, they restrict their lives within the borders of this technological world. However, teenagers think that the use of technology especially mobile phones improves their social status: Therefore, they feel more attached to them (Yilmaz, Sar \& Civan, 2015). Kim et al. (2012) reported that adolescents have the tendency to concentrate while using media and can develop more habitual usage problems than adults when they are introduced to a new type of media. Besides, teenagers are more prone to smartphone addiction compared to adults (Kwon, Kim, Cho \& Yang, 2013).

It is seen that most of the studies in the literature were carried out over university students. However, the need for socializing in the adolescent stage when the personality is being developed has a priority and this need of communication is mostly achieved through smartphones and mobile internet in virtual platforms but not face-to-face. Consequently, it is thought that this can increase smartphone attachment and dependence of adolescents in high schools so this can have a negative result like nomophobia. Therefore, we think that it is necessary to examine the effects of nomophobia on daily and school life basis through studies considering learning, social cognition and technology-human-being relationship in teenagers (King et al., 2013).

Within this context, the purpose of this study is not only to examine the level of nomophobia prevalence among high school students between the grades of 9-12 in diverse socio-economic areas in different cities in Turkey but also, to examine whether the prevalence of nomophobia differ in terms of the factors such as gender, parents' education levels, the duration of smartphone and mobile internet usage. Besides, the level of high school students' mobile internet usage will be examined.

In accordance with this general purpose, the answers to the following questions are tried to be found.

1) What is the aims of smartphone usage?

2) In terms of adolescents' nomophobia level,

a) Is there a difference in terms of gender?

b) Is there a difference in terms of class levels?

c) Is there a difference in terms of parents' educational backgrounds?

d) Is there a difference in terms of smartphone usage time?

e) Is there a difference in terms of mobile internet usage?

\section{Method}

This study employed a causal-comparative research design, which focuses on the causes and consequences of the differences that are already present among participants (Fraenkel et al., 2012). Accordingly, it is tried to determine the causes for and consequences of the differences among the participants regarding their nomophobic behaviors. 


\subsection{Study group}

Randomly selected 536 high school students from 6 high schools in different socio-economic neighborhood in Edirne and Izmir participated in the study but 41 students were excluded from the study since they did not have a smartphone and 20 students were left outside the study as they did not complete the questionnaire. Therefore, the study group is formed with 475 high school students. Demographic properties of the students were given in Table 1.

Table 1. Demographic properties of high school students

\begin{tabular}{|c|c|c|}
\hline City & $\mathrm{N}$ & $\%$ \\
\hline Izmir & 166 & 34,9 \\
\hline Edirne & 309 & 65,1 \\
\hline \multicolumn{3}{|l|}{ Gender } \\
\hline Female & 259 & 54,5 \\
\hline Male & 216 & 45,5 \\
\hline \multicolumn{3}{|l|}{ Type of high school } \\
\hline Anatolian high school & 260 & 54,7 \\
\hline Vocational and technical Anatolian high school & 136 & 28,6 \\
\hline Social sciences high school & 64 & 13,5 \\
\hline Religious vocational high school & 15 & 3,2 \\
\hline \multicolumn{3}{|l|}{ Grade } \\
\hline 9th Grade & 263 & 55,4 \\
\hline 10th Grade & 89 & 18,7 \\
\hline 11th Grade & 78 & 16,4 \\
\hline 12th Grade & 45 & 9,5 \\
\hline \multicolumn{3}{|l|}{ Mother's education level } \\
\hline No education & 22 & 4,6 \\
\hline Primary school & 177 & 37,3 \\
\hline Secondary school & 129 & 27,2 \\
\hline High school & 120 & 25,3 \\
\hline Undergraduate & 20 & 4,2 \\
\hline Graduate -Phd & 7 & 1,5 \\
\hline \multicolumn{3}{|l|}{ Father's education level } \\
\hline No education & 3 & 0,6 \\
\hline Primary school & 125 & 26,3 \\
\hline Secondary school & 133 & 28,0 \\
\hline High school & 154 & 32,4 \\
\hline Undergraduate & 37 & 7,8 \\
\hline Graduate-Phd & 23 & 4,8 \\
\hline \multicolumn{3}{|l|}{ Duration of smartphone usage } \\
\hline Less than one year & 112 & 23,6 \\
\hline Between 1- 4 years & 285 & 60,0 \\
\hline More than 4 years & 78 & 16,4 \\
\hline \multicolumn{3}{|l|}{ Duration of mobile internet usage } \\
\hline Less than one year & 129 & 27,2 \\
\hline Between 1 - 4 years & 271 & 57,0 \\
\hline More than 4 years & 75 & 15,8 \\
\hline Total & 475 & 100 \\
\hline
\end{tabular}




\subsection{Data collection tools}

Demographic information form and nomophobia scale were used in this study.

\subsubsection{Demographic information}

In the demographic information form, there is information about gender, type of high school, class level, parents' education level, duration of smartphone and mobile internet use and the aims for using them.

\subsubsection{Nomophobia scale (NMP-Q)}

Nomophobia Scale (NMP-Q), which was developed by Yildirim and Correia (2015) and adapted into Turkish by Yildirim, Sumuer, Adnan, and Yildirim (2015) was used in the study. The scale was itemized according to 7 Likert Type and included 20 items. The reliability coefficient of the original scale was calculated as .95 by using Cronbach's Alpha and the reliability coefficient of Turkish version was found as .92 . As is known, having this value over .80 means that this scale has a high reliability (Field, 2005) The scale has four sub- dimensions. Not Being Able to Access Information (4 items), Losing Connectedness (5 items), Not Being Able to Communicate (6 items) and Giving up Convenience (5 items). In the original scale, the reliability coefficients of these sub-dimensions were given as in the order, $.94, .87, .83$ and .81 . The reliability coefficients of the scale were reported as $.90, .74, .94$ and .91 .

\subsection{Data collection and analysis}

In the study, data collection process was determined and based on the voluntary participation of university students by the researchers. The analysis was done by using the packet program of SPSS 23.0 (The Statistical Package for the Social Sciences). Some statistical techniques like standard deviation, mean, t-test and one-way analysis of variance (ANOVA) were used during the analysis stage. Independent samples t-test was used to determine high school students' nomophobia levels in terms of gender. In addition, one-way analysis of variance (ANOVA) was done to determine high school students' nomophobia levels in terms of the type of school, class level, parents' education level, duration of smartphone and mobile internet use. Kolmogorov-Smirnov test was used to control normal distribution and it was found that normal distribution values were smaller than the level of statistical significance $(\mathrm{p}<.05)$. Hence, the values of Skewness and Kurtosis were used to measure normal distribution. As is known, in the cases of a high number of participants in the study group, having the value of Skewness and Kurtosis in between \pm 1.96 generates normality hypothesis (Tabachnick and Fidell, 2007). It was found that obtained findings generate normality hypothesis and the problems of extensive Kurtosis and Skewness did not exist. After descriptive statistics about the scores were obtained, Levene Test ( $\mathrm{p}>.05)$ was used to control the variance homogeneity of comparable groups. Statistical significance level was taken as .05 in the statistical analysis.

\section{Results}

Table 2. Means and standard deviations of the scale and sub-dimensions

\begin{tabular}{lcccc}
\hline & Min & Max & $\overline{\mathbf{X}}$ & Standard Deviation \\
\hline Not being able to access information & 1,00 & 7,00 & 3,82 & 1,749 \\
Losing connectedness & 1,00 & 7,00 & 3,76 & 1,727 \\
Not being able to communicate & 1,00 & 7,00 & 4,10 & 1,840
\end{tabular}


Gezgin, D. M., \& Çakır, Ö. (2016). Analysis of nomofobic behaviors of adolescents regarding various factors. Journal of Human Sciences, 13(2), 2504-2519. doi:10.14687/jhs.v13i2.3797

\begin{tabular}{lllll}
\hline Giving up convenience & 1,00 & 7,00 & 3,12 & 1,820 \\
\hline Total & 1,00 & 7,00 & 3,72 & 1,456 \\
\hline
\end{tabular}

Based on the mean scores $(\bar{X}=3,72)$ obtained from Nomophobia Scale, it was discovered that nomophobia levels of high school students are a little bit higher than average. When the subdimensions of the scale were examined, it was seen that the scores obtained from the subdimensions of Not Being Able to Access Information $(\bar{X}=3,82)$, Losing Connectedness $(\bar{X}=3,76)$ and Not Being Able to Communicate were above the average. Only the score obtained from the dimension of Giving up Convenience $(\bar{X}=3,12)$ was found to be below the average (Table 2).

\subsection{The aim of smartphone usage}

When it is examined the aim of smartphone usage, it was found that $89.3 \%$ of high school students use mobile internet for social networking, $78.3 \%$ of them for Music, $75.2 \%$ for Communication, 60.8\% for Photograph, $57.7 \%$ for Education and Research, $57.1 \%$ for Game, $55.2 \%$ for Video, $33.3 \%$ for News, $30.3 \%$ for shopping, $18.9 \%$ for E-Book and $15.6 \%$ use it for Navigation (Table3).

Table 3. High School Students' Aims to Use Smartphone and Mobile Internet

\begin{tabular}{lcc|cc}
\hline & \multicolumn{2}{c}{ Yes } & \multicolumn{2}{c}{ No } \\
& $\mathrm{N}$ & $\%$ & $\mathrm{~N}$ & $\%$ \\
\hline Social Network & 425 & 89,5 & 50 & 10,5 \\
Music & 372 & 78,3 & 103 & 21,7 \\
Communication & 357 & 75,2 & 118 & 24,8 \\
Photograph & 289 & 60,8 & 186 & 39,2 \\
Education and Research & 274 & 57,7 & 201 & 42,3 \\
Game & 271 & 57,1 & 204 & 42,9 \\
Video & 262 & 55,2 & 213 & 44,8 \\
News & 158 & 33,3 & 317 & 66,7 \\
Shopping & 144 & 30,3 & 331 & 69,7 \\
E-Book & 90 & 18,9 & 385 & 81,1 \\
Navigation & 74 & 15,6 & 401 & 84,4 \\
\hline
\end{tabular}

\subsection{Findings on gender}

Random sampling t-test was done with the aim of revealing whether nomophobia level of high school students differs in terms of gender. According to the results of random sampling t-test, a statistically significant difference $[\mathrm{t}(473)=4.70, \mathrm{p}<.05]$ was found between female students $(\mathrm{M}=4.00, \mathrm{SS}=1.45)$ and male students $(\mathrm{M}=3.38, \mathrm{SS}=1.40)$ in terms of their nomophobia levels. Based on this finding, it can be said that female students have higher tendency to exhibit nomophobic behaviors $(\eta 2=0,200)$ (Table 4).

Table 4. Results of Random Sampling t-test Analysis in terms of Gender

\begin{tabular}{lccccccc}
\hline Gender & $\mathrm{N}$ & $\bar{X}$ & $\mathrm{SS}$ & $\mathrm{df}$ & $\mathrm{t}$ & $\mathrm{p}$ & $\eta 2$ \\
\hline Female & 259 & 4,00 & 1,45 & \multirow{2}{*}{473} & 4,70 &, $00^{*}$ & 0,200 \\
Male & 216 & 3,38 & 1,40 & & & & \\
\hline
\end{tabular}

${ }^{*} \mathrm{p}<0.05$ There was a significant difference. 
Gezgin, D. M., \& Çakır, Ö. (2016). Analysis of nomofobic behaviors of adolescents regarding various factors. Journal of Human Sciences, 13(2), 2504-2519. doi:10.14687/jhs.v13i2.3797

\subsection{Findings on class levels}

One-way variance analysis (ANOVA) was administered to reveal whether nomophobia level of high school students differs in terms of class levels. According to the results of analysis, a significant difference could not be found between the nomophobia level of high school students in terms of class levels $[\mathrm{F}(3,471)=.380, \mathrm{p}=.767]$. According to the finding, it can be said that class level, which could also be considered as age, does not have any impact on the prevalence of nomophobia among high school students in terms of class levels $(\eta 2=0,002)$ (Table 5).

Table 5. Results of ANOVA in terms of class levels

\begin{tabular}{lcccccc}
\hline Variance Source & Sum of Squares & df & Mean Squares & F & p & $\eta 2$ \\
\hline Intergroups & 2,429 & 3 &, 810 & & & \\
Within groups & 1002,872 & 471 & 2,129 & \multirow{2}{*}{380} &, 767 & 0,002 \\
Total & 1005,301 & 474 & & & & \\
& & & & & & \\
\hline
\end{tabular}

\subsection{Findings on mother's education level}

One-way variance analysis (ANOVA) was applied to find out whether nomophobia level of high school students differs in terms of mother's education level. According to the results of the analysis, a significant difference could not be found between high school students' nomophobia level in terms of mother's education level $[\mathrm{F}(5,469)=1,760, \mathrm{p}=.113]$. It might be said that mother's education level has no impact on the prevalence of nomophobia $(\eta 2=0,019)$ (Table 6$)$.

Table 6. Results of ANOVA in terms of mother's education level

\begin{tabular}{lcccccc}
\hline Variance Source & Sum of Squares & $\mathrm{df}$ & Mean Squares & F & $\mathrm{p}$ & $\eta 2$ \\
\hline Intergroups & 18,827 & 5 & 3,765 & & & \\
Within Groups & 986,474 & 469 & 2,103 & 1,790 & \multirow{2}{*}{113} & 0,019 \\
Total & 1005,301 & 474 & & & & \\
\hline
\end{tabular}

\subsection{Findings on father's education level}

One-way variance analysis (ANOVA) was done to find out if nomophobia level of high school students differs in terms of father's education level. According to the results of the analysis, a significant difference could not be found between nomophobia level of high school students in terms of father's education level $[\mathrm{F}(5,469)=, 424, \mathrm{p}=.832]$. Therefore, it could be said that father's education level has no impact on the prevalence of nomophobia $(\eta 2=0,005)$ (Table 7).

Table 7. Results of ANOVA in terms of father's education level

\begin{tabular}{lcccccc}
\hline Variance Source & Sum of Squares & $\mathrm{df}$ & Mean Squares & $\mathrm{F}$ & $\mathrm{p}$ & $\eta 2$ \\
\hline Intergroups & 4,525 & 5 &, 905 & & & \\
Within Groups & 1000,776 & 469 & 2,134 & \multirow{2}{*}{424} & \multirow{2}{*}{832} & 0,005 \\
Total & 1005,301 & 474 & & & & \\
\hline
\end{tabular}

\subsection{Finding on smartphone usage time}

ANOVA was done to find out if nomophobia level of high school students differs in terms of smartphone usage time. According to the results of the analysis, a significant difference could not be found between nomophobia level of high school students in terms of smartphone usage time 
Gezgin, D. M., \& Çakır, Ö. (2016). Analysis of nomofobic behaviors of adolescents regarding various factors. Journal of Human Sciences, 13(2), 2504-2519. doi:10.14687/jhs.v13i2.3797

$[\mathrm{F}(2,472)=1,248, \mathrm{p}=.288]$. Therefore, it could be said that smartphone usage time has no impact on the prevalence of nomophobia $(\eta 2=0,005)$ (Table 8 ).

Tablo 8. Results of ANOVA in terms of smartphone usage time

\begin{tabular}{lcccccc}
\hline Variance Source & Sum of Squares & $\mathrm{df}$ & Mean Squares & F & $\mathrm{p}$ & $\eta 2$ \\
\hline Intergroups & 5,289 & 2 & 2,644 & & & \\
Within Groups & 1000,012 & 472 & 2,119 & 1,248 & \multirow{2}{*}{288} & 0,005 \\
Total & 1005,301 & 474 & & & & \\
\hline
\end{tabular}

3.7. Findings on mobile internet usage

One-way variance analysis (ANOVA) was done to determine whether nomophobia level of high school students differs in terms of the duration of mobile internet usage. According to the results of the analysis, there is a significant difference between nomophobia level of high school students in terms of mobile internet usage $[\mathrm{F}(2,472)=3,170, \mathrm{p}=, 043]$ (Table 9).

Table 9. The Results of ANOVA in terms of mobile internet usage

\begin{tabular}{lccccccc}
\hline Variance Source & Sum of Squares & df & Mean Squares & F & p & $\begin{array}{c}\text { Significant } \\
\text { Difference }\end{array}$ & $\eta 2$ \\
\hline Intergroups & 13,324 & 2 & 6,662 & & & & \\
Within Groups & 991,977 & 472 & 2,102 & 3,170 &, $043^{*}$ & B-C & 0,013 \\
Total & 1005,301 & 474 & & & & & \\
\hline
\end{tabular}

(A: Less than 1 year, B: Between 1-4 years, C: More than 4 years)

${ }^{*} \mathrm{p}<0.05$ There was a significant difference.

TUKEY test was used to determine which groups have significant difference. According to the findings, a significant difference was found between the group which uses mobile internet between $1-4$ years $(M=3.65, S S=1.45)$ and the group which uses mobile internet for more than 4 years. It was found that this difference was in favor of the student group, which uses mobile internet for more than 4 years. An increase in the duration of mobile internet usage causes a raise in nomophobic behaviors $(\eta 2=0,013)$.

\section{Discussion}

In the study in which the prevalence of nomophobia was investigated, it was found that nomophobia levels of the students who participated in this study were above the average and they tend to exhibit nomophobic behaviors. Especially the scores that the students got from the subdimensions of nomophobia scale like "not being able to communicate and "not being able to access information" were remarkable. Other studies back up the findings of this study. In a study conducted by Gezgin and Adnan (2016) with 433 university students, it was stated that the prevalence of nomophobia among students was proved to be above the average. In another study carried out by Yildirim et al. (2015) with the participation of 537 university students, it was revealed that $42.6 \%(\mathrm{n}=206)$ of the students have nomophobic behaviors and the factors like "not being able to communicate" and "not being able to access information" have the most significance among young people. In addition to these studies, in a study done in India with the participation of medical students, it was revealed that nearly $73 \%$ of the students were nomophobic (Tavolacci et al., 2015). In another study carried out by SecureEnvoy in England in 2012, 77 \% of young people who are between the ages of 18-24 said that the idea of losing their mobile phones creates anxiety and they feel fear in this sense (SecurEnvoy, 2012). 
The aims of high school students to use mobile internet are also examined in the study. According to the findings, it was found that $89.3 \%$ of high school students use mobile internet for social networking, $78.3 \%$ of them for Music, $75.2 \%$ for Communication, $60.8 \%$ for Photograph, $57.7 \%$ for Education and Research, $57.1 \%$ for Game, $55.2 \%$ for Video, $33.3 \%$ for News, $30.3 \%$ for shopping, $18.9 \%$ for E-Book and $15.6 \%$ use it for Navigation. Lemola et al. (2015) showed that adolescents who owned a smartphone sent a lot more text messages to communicate and spent more time on the Internet and on Facebook everyday than their peers with conventional mobile phones while they did not watch more TV or play video games. In another study conducted by Istanbul Provincial Directorate of National Education, Internet Development Committee and Google with the participation of 13.500 students, it was reported that $80 \%$ of the students have smartphones and $75 \%$ of them access the Internet through their smartphones. According to the same report, it was stated that students use mobile internet in order to do homework and assignments $(77 \%)$, listen to music $(72 \%)$, do research $(68 \%)$, watch videos $(60 \%)$, chat $(60 \%)$, communicate $(59 \%)$, play games $(45 \%)$, do shopping $(19 \%)$ and make friends $(15 \%)$ (Milliyet, 2016).

When the findings of the study were examined in terms of gender, a significant difference was detected between female and male students in terms of nomophobia levels. Accordingly, the tendency of showing nomophobic behaviors is higher in girls compared to boys. To back up the findings of the study, in a study conducted by Yildirim et al. (2015) with the participation of university students, it was found that nomophobia level of female students is higher compared to male students. In the study carried out by SecurEnvoy (2012), it was reported that women $(70 \%)$ are more anxious than men (61\%) when their mobiles are off or not having their telephones with them. According to the findings of a research, it was reported that mobile devices are mostly preferred as a leisure device and $48 \%$ of women participants and $36 \%$ of male participants have the tendency of using their mobiles as a leisure tool (MobiRoller, 2014). In a study conducted by Tavolacci et al. (2015) on the effects of nomophobia, it was found that female students are more affected compared to boys. Some other studies drew conclusions opposite the findings of this study. In a study conducted in India by Dixit et al. (2010), they could not find a difference between the levels of nomophobia in terms of gender. When smartphone addiction was examined, Hwong, Yoo and Cho (2012) discovered in their study that female students are more prone to smartphone addiction compared to male students. Besides, considering the fact that the score obtained from the sub-dimension of "not being able communicate" is high, this difference occurred because of gender means that female students are more dependent on their mobiles and their smartphones are more important compared to male students (Karaaslan and Budak, 2012).

A significant difference could not be found between high school students about the prevalence of nomophobia in terms of class levels. In the light of the findings of the study conducted by Gezgin and Adnan (2016) with the participation of 433 university students, a significant difference was not found between the students about the prevalence of nomophobia in terms of class levels. Some other studies have opposite findings. In a study carried out by SecureEnvoy (2012), it was found that nomophobia levels of students between the ages of 18-24 are higher $(77 \%)$ than those who are between the ages of 25-34 (68\%). Similarly, in a study conducted by Yildirim et al. (2015), it was reported that there was not a significant difference between the students who are 20 and younger and those who are over 20 in terms of nomophobia levels. In this study, 263 (54.6\%) students from 9th graders could be reached but as a limitation, only 45 of 12th graders were reached because they have a preparation period to take university entrance exam. In this context, increasing the number of participants will enable us to determine the possible difference. Another issue is that comparing and contrasting high school students and university students might provide us with the data to determine the impact of class level and age on nomophobia prevalence. When the samples 
of high school students and university students were examined, it could be seen that the ages of the participants within both groups are very close to each other.

A significant difference could not be found between the prevalence of nomophobia level of high school students in terms of both parents' education levels.

When the findings of the study were examined in terms of the duration of smartphone usage, a significant difference could not be found on the prevalence of nomophobia level of high school students. In the study conducted with university students, Yildirim et al. (2015) could not find a significant difference on the nomophobia level of students in terms of the duration of smartphone usage by the help of the findings of this study. On the contrary, when the items of the scale and the definition of nomophobia were examined, it is thought that there is a positive relationship between the duration of smartphone usage and the prevalence of nomophobia. This is an unexpected finding for the researchers. Contrary to these findings, some studies asserted that the duration of smartphone usage could have an impact on nomophobia with the prevalence of smartphone usage. In a study done by Kalaskar (2015), $90 \%$ of the students who participated in the study said that they had been using a smartphone for more than two years. In the same study, it was found that those who spend for 5-6 hours on their smartphones are more prone to the effects of nomophobia such as anxiety, sleeping disturbances, stress, losing interest or motivation towards lessons...etc. There are some other studies indicating that a rise in the duration of smartphone usage increases nomophobia level (Yildirim \& Correia, 2015; Yildirim et al., 2015). However, based on the findings of the study, it could be said that nomophobia level does not directly depend on the duration of smartphone usage.

When the findings of the study in terms of the duration of mobile internet usage were examined, a significant difference was found on the nomophobia levels of high school students. According to the findings that gave the result of significant difference, the difference between the high school students who use mobile internet for 1-4 years and for more than 4 years was in favor of the students who use mobile internet for more than 4 years. Based on this result, it can be said that the longer the duration of mobile internet use, the more nomophobic behaviors they exhibit. While an increase in the duration of smartphone usage of high school students has no effect on nomophobia, an increase in the duration of mobile internet usage that they use in their smartphones does have an effect on nomophobia. The fact that the scores that high school students got from the sub-dimensions of "not being able access information" $(\bar{X}=3,82)$ and "not being able to communicate" ( $\bar{X}=4,10)$ were above the average supports this result. In addition, the fact that they use mobile internet for Social Networking, Communication, Photograph and Education-Research is another reason that backs up this result. In the future, it is suggested that studies be conducted to examine the relationship between internet addiction and nomophobia. How much smartphone affect the tendency of showing nomophobic behavior without mobile internet could be investigated thanks to these studies. It could be seen in the study that the duration of mobile internet usage has more impact on nomophobia than the duration of smartphone usage. The development of mobile technologies like $4.5 \mathrm{G}$ could increase the prevalence of nomophobia.

\section{Conclusion and Suggestions}

As a conclusion, based on the findings of the study, it was revealed that nomophobia is prevalent among high school students. It is observed that the fear and anxiety resulted from nomophobia affect an individual's life negatively. Especially, it might affect students' academic performance. Therefore, it is necessary to observe and examine the effects of nomophobia on students' ordinary and academic life by conducting studies on young people in terms of learning, social cognition and 
technology-human relationship (King et al., 2013). Although there are not any studies in the literature about the effect of nomophobia on students' academic success, studies asserting that smart/mobile phone usage affect students' academic success support this finding (Jacobsen and Forste ,2011; Lepp, Barkley, \& Karpinski, 2015;Samaha \& Hawi, 2016; Sanchez Martinez and Otero, 2009 ;Yen et al., 2009). Future studies to examine the relationship between the negative effects of nomophobia and students' academic performance is suggested to be carried out. In addition to this, in the light of the data revealing an increase in the duration of mobile internet use affects the level of nomophobia prevalence, it could be said that smartphone usage is not directly associated with nomophobia and is dependent on different factors such as the duration of mobile internet use. It has become very important to conduct studies that will examine the relationship between internet addiction and nomophobia for future studies. Besides, it is necessary to raise awareness about nomophobia by informing students, parents, teachers and psychological counselors. Thus, it will be possible to fight against and eliminate the effects of nomophobia. Nowadays, teachers use mobile devices in their lessons and some activities have been done to increase students' learning motivation and academic success through some special mobile learning practices. However, they must pay attention to the danger of nomophobia while using mobile devices and applying mobile learning practices. It was reported that the use of smartphones in educational environments could have some risks and side effects such as dependence, attentiondeficit-disorder, empathy disorder, and a decrease in academic achievement, distractions or an interruption in educational activities, hypertension, obesity, anxiety, depression, personality disorder, aggression, dissatisfaction and loneliness (Spitzer, 2015). Teachers and parents must have a system of controlled use of mobile phones and mobile learning practices and they must put a time limit for their children and students. Furthermore, it is thought that in mobile learning software systems, the software system must allocate a time limit for students and not allow them to access to the system until the next login would support teachers and parents in dealing with the risks and side effects of nomophobia. Consequently, learning would be more effective after minimizing and eliminating potential risks of smartphones and mobile learning platforms in education.

\section{References}

Gezgin D.M., \& Adnan M. (2016), “Modern Yüzyllın Yeni Olgusu Nomofobi ve Üniversite Öğrencileri Arasında Yaygınlık Düzeyi", 10th International Computer \& Instructional Technologies Symposium, 16-18 May, Rize/Turkey

Berson, I., \& Berson, M. (2003). Digital literacy for effective citizenship. Social Education, 67(3), 164- 167

Chen, B., \& Denoyelles, A. (2013). Exploring students' mobile learning practices in higher education. Educause Review. Retrieved from http://www. educause. edu/ero/article/exploring-students-mobile-learning-practices-higher-education.

Chen Y.F., \&Katz J. (2009), "Extending Family to School Life: College Students Use of the Mobile Phone", Human-Computer Studies, vol. 67

Dixit, S., Shukla, H., Bhagwat, A., Bindal, A., Goyal, A., Zaidi, A., \& Shrivastava, A. (2010). A study to evaluate mobile phone dependence among students of a medical college and associated hospital of central India. Indian Journal of Community Medicine, 35(2), 339.

Fraenkel JR, Wallen NE and Hyun HH (2012) How to Design and Evaluate Research in Education. New York, N.Y.; London: McGraw-Hill Higher Education.

Hassoy H, Durusoy R, Karababa AO.( 2013) Adolescents' risk perceptions on mobile phones and their base stations, their trust to authorities and incivility in using mobile phones: a cross- 
sectional survey on 2240 high school students in Izmir, Turkey. Environ Health;12:1-10.

Hwang KH, Yoo YS, Cho OH.(2012). Smartphone overuse and upper extremity pain, anxiety, depression, and interpersonal relationship among college students. The Journal of the Korea Contents Association. 12(10):365-75

Jacobsen, W. C., \& Forste, R. (2011). The wired generation: Academic and social outcomes of electronic media use among university students. Cyberpsychology, Behavior, and Social Networking, 14(5), 275-280.

Judd, T. (2014). Making sense of multitasking: The role of Facebook. Computers \& Education, 70, 194-202.

Kalaskar, P. B. (2015). A study of awareness of development of NoMoPhobia condition in smartphone user management students in Pune city. INCON 2015. E-issn-2320-0065.

Karaaslan, İ. A., \& Budak, L. (2012). Üniversite Öğrencilerinin Cep Telefonu Özelliklerini Kullanımlarının ve Gündelik İletişimlerine Etkisinin Araştırılması. Journal of Yasar University, 26(7), 4548-4525.

Karpinski, A. C., Kirschner, P. A., Ozer, I., Mellott, J. A., \& Ochwo, P. (2013). An exploration of social networking site use, multitasking, and academic performance among United States and European university students. Computers in Human Behavior, 29(3), 1182-1192.

Kibona, L., \& Mgaya, G. (2015). Smartphones' Effects on Academic Performance of Higher Learning Students. Journal of Multidisciplinary Engineering Science and Technology, 2(4), 777-784.

Kim DI, Lee YH, Lee JY, Kim MC, Keum CM, et al. (2012) New Patterns in Media Addiction: Is Smartphone a Substitute or a Complement to the Internet? The Korean Journal of Youth Counseling 20(1): 71-88.

King, A.L.S., Valença, A.M., Silva, A.C., Baczynski, T., Carvalho, M.R. \& Nardi, A.E. (2013). Nomophobia: dependency on virtual environments or social phobia? Computers in Human Behavior, 29(1) (2013), pp. 140-144. http://dx.doi.org/10.1016/j.chb.2012.07.025.

Kwon, M., Kim, D. J., Cho, H., \& Yang, S. (2013). The smartphone addiction scale: development and validation of a short version for adolescents. PloS one,8(12), e83558.

Ko, C. H., Yen, J. Y., Yen, C. F., Chen, C. S., \& Chen, C. C. (2012). The association between Internet addiction and psychiatric disorder: a review of the literature. European Psychiatry, 27(1), 1-8.

Korean Internet and Security Agency(2012). Intervention and resolution strategy for smart media addiction.

Lemola, S., Perkinson-Gloor, N., Brand, S., Dewald-Kaufmann, J. F., \& Grob, A. (2015). Adolescents' electronic media use at night, sleep disturbance, and depressive symptoms in the smartphone age. Journal of youth and adolescence, 44(2), 405-418.

Lepp, A., Barkley, J. E., \& Karpinski, A. C. (2015). The relationship between cell phone use and academic performance in a sample of US college students. SAGE Open, 5(1), 2158244015573169.

Lepp, A., Barkley, J. E., Sanders, G. J., Rebold, M., \& Gates, P. (2013). The relationship between cell phone use, physical and sedentary activity, and cardiorespiratory fitness in a sample of US college students. International Journal of Behavioral Nutrition and Physical Activity, 10(1), 79.

Li, J., Lepp, A., \& Barkley, J. E. (2015). Locus of control and cell phone use: Implications for sleep quality, academic performance, and subjective well-being. Computers in Human Behavior, 52, 450-457. 
Gezgin, D. M., \& Çakır, Ö. (2016). Analysis of nomofobic behaviors of adolescents regarding various factors. Journal of Human Sciences, 13(2), 2504-2519. doi:10.14687/jhs.v13i2.3797

Milliyet(2016). “Gençler, saatlerce internette ne yapıyor?”. Bilinçli İnternet Kullanımı Araştırması. İstanbul

MobiReller (2014). "Mobil kullanıcı alışkanlıkları", http://www.mobiroller.com/tr/mobil-kullanicialiskanliklari/ sitesinden 04.04.2016 tarihinde erişildi.

Rideout, V. J., Foehr, U. G., \& Roberts, D. F. (2010). Generation M2 : Media in the lives of 8- to 18-year-olds. Menlo Park: Henry J. Kaiser Family Foundation

Rosen, L. D., Carrier, L. M., \& Cheever, N. A. (2013). Facebook and texting made me do it: Mediainduced task-switching while studying. Computers in Human Behavior, 29(3), 948-958.

Samaha, M., \& Hawi, N. S. (2016). Relationships among smartphone addiction, stress, academic performance, and satisfaction with life. Computers in Human Behavior, 57, 321-325.

Sánchez-Martínez, M., \& Otero, A. (2009). Factors associated with cell phone use in adolescents in the community of Madrid (Spain). CyberPsychology \& Behavior, 12(2), 131-137.

Sarrab M. (2015). Mobile Learning (m-learning) Concepts, Characteristics, Methods, Components: Platforms and Frameworks. 2015.

SecurEnvoy. (2012). 66\% of the population suffer from Nomophobia the fear of being without their phone. https://www.securenvoy.com/blog/2012/02/16/66-of-the-population-sufferfrom-nomophobia-the-fear-of-being-without-their-phone/. 13 Mart 2016 tarihinde erişilmiştir.

Sharma, N., Sharma, P., Sharma, N. \& Wavare, R. R. (2015). Rising concern of nomophobia amongst Indian medical students. International Journal of Research in Medical Sciences, 3(3), 705-707. doi:10.5455/2320-6012.ijrms20150333.

Smith, A. (2015). US smartphone use in 2015. Pew Research Center, 18-29.

Smith, A., Raine, L., \& Zickuhr, K. College students and technology. 2011. The Pew Research Center's Internet and American Life Project.

Szpakow, A., Stryzhak, A., \& Prokopowicz, W. (2011). Evaluation of threat of mobile phoneaddition among Belarusian University students. Prog Health Sci,1(2), 96-100.

Tan, G. W. H., Ooi, K. B., Leong, L. Y., \& Lin, B. (2014). Predicting the drivers of behavioral intention to use mobile learning: A hybrid SEM-Neural Networks approach. Computers in Human Behavior, 36, 198-213.

Tavolacci, M. P., Meyrignac, G., Richard, L., Dechelotte, P., \& Ladner, J. (2015). Problematic use of mobile phone and nomophobia among French college students. The European Journal of Public Health, 25(suppl 3), ckv172-088.

Tindell, D. R., \& Bohlander, R. W. (2012). The use and abuse of cell phones and text messaging in the classroom: A survey of college students. College Teaching, 60(1), 1-9.

Toteja, R., \& Kumar, S. (2012). Usefulness of m-devices in education: A survey. Procedia-Social and Behavioral Sciences, 67, 538-544.

TUIK. (2015). "Hanehalkı Bilişim Teknolojileri Kullanım Araştırması". [Online] Retrieved on 2603-2016, at URL: http://www.tuik.gov.tr/PreHaberBultenleri.do?id=18660.

Yang, C. C., Hwang, G. J., Hung, C. M., \& Tseng, S. S. (2013). An Evaluation of the Learning Effectiveness of Concept Map-Based Science Book Reading via Mobile Devices. Educational Technology \& Society, 16(3), 167-178.

Yen, C. F., Tang, T. C., Yen, J. Y., Lin, H. C., Huang, C. F., Liu, S. C., \& Ko, C. H. (2009). Symptoms of problematic cellular phone use, functional impairment and its association with depression among adolescents in Southern Taiwan.Journal of Adolescence, 32(4), 863873. 

Human Sciences, 13(2), 2504-2519. doi:10.14687/jhs.v13i2.3797

Yildirim, C. \& Correia A-P. (2015). Exploring the dimensions of nomophobia: Development and validation of a self-reported questionnaire. Computers in Human Behavior, 49, 130-137.

Yildirim, C., Sumuer, E., Adnan, M., \& Yildirim, S. (2015). A growing fear: Prevalence of nomophobia among Turkish college students. Information Development, 0266666915599025.

Yılmaz, G., Şar, A. H., \& Civan, S. (2015). Investigation of Adolescent Mobile Phone Addiction by Social Anxiety Effect of Some Variable. Online Journal of Technology Addiction \& Cyberbullying, 2(4).

Yenilmez Ç. (2013), “Cep telefonsuzluk artk fobi”, http://www.posta.com.tr/saglik/HaberDetay/Cep-telefonsuzluk-artikfobi.htm?ArticleID=159283 adresinden 04.04 tarihinde erişilmiştir.

We are Social (2015), Global İnternet Ve Sosyal Medya Kullanıc1 İstatistikleri, http://www.slideshare.net/wearesocialsg/digital-social-mobile-in-2015 , 26.03.2016 tarihinde erişildi.

Wentworth, D. K., \& Middleton, J. H. (2014). Technology use and academic performance. Computers \& Education, 78, 306-311.

Willemse, I., Waller, G., Su"ss, D., Genner, S., \& Huber, A.-L. (2012). JAMES - Jugend, Aktivita"ten, Medien - Erhebung Schweiz. Zu"rich: Zu"rcher Hochschule fu"r Angewandte Wissenschaften. 